\title{
Discrepancy in the lower arch perimeter in patients with a unilateral cleft lip and palate: orthodontic model analysis
}

\author{
Ayşe Gülşen (iD, ${ }^{1}$ Belma Işık Aslan (D), ${ }^{2}$ \\ Fatma Deniz Uzuner iD, ${ }^{2 *}$ Gülce Tosun (D), ${ }^{2}$ \\ Neslihan Üçüncü (iD ${ }^{2}$ \\ ${ }^{1}$ Department of Plastic and Reconstructive Surgery, Faculty \\ of Medicine, ${ }^{2}$ Department of Orthodontics, Faculty of \\ Dentistry, Gazi University, Ankara, Turkey
}

\begin{abstract}
OвJEctive: This study aimed to assess the lower arch length discrepancy in a group of patients with unilateral cleft lip and palate (UCLP).

Materials and Method: Pretreatment dental casts and panoramic radiographs of 23 patients (aged 9-19 years) with a nonsyndromic complete UCLP, without having large restorations/crowns, tooth agenesis, impacted or supernumerary teeth in the lower arch, and previous orthodontic and/or prosthetic treatment, were evaluated. All patients underwent lip and palate repair. Lower arch discrepancies were determined using the Hayes-Nance analysis. Panoramic radiographs were used to estimate the size of permanent premolars for the patients with late mixed dentition. The positive discrepancy defined diastema, whereas the negative discrepancy defined crowding in the lower arch. Descriptive statistics were presented using frequencies and percentages, and the differences were evaluated using the binomial test.
\end{abstract}

Results: One out of 23 patients had no discrepancy in the lower arch. For the remaining patients $(n=22)$, the prevalence of diastema was $47.8 \%(n=10)$, with a mean value of $3.6 \pm 1.9 \mathrm{~mm}$, and lower arch crowding was observed in $52.2 \%(n=12)$, with a mean value of $-2.9 \pm 1.4 \mathrm{~mm}$. No significant difference was found between the prevalence of crowding and diastema $(p=0.832)$.

CONCLUSION: In patients with a UCLP, diastema can be encountered approximately at the same frequency as crowding in the lower arch. Crowding was at a low to mid-level.

KEYwords: Crowding; dental arch; diastema

Citatıon: Gülşen A, Işık Aslan B, Uzuner FD, Tosun G, Üçüncü $N$. Discrepancy in the lower arch perimeter in patients with a unilateral cleft lip and palate: orthodontic model analysis. Acta

Received: May 17, 2018; Accepted: November 28, 2018

${ }^{*}$ Corresponding author: Dr. Fatma Deniz Uzuner, Department of Orthodontics, Faculty of Dentistry, Gazi University, Bişkek Cad. (8. Cadde), 82. Sokak,

06510, Emek, Ankara, Turkey;

E-mail: fduzuner@yahoo.com.tr
Odontol Turc 2019;36(1):16-20

EdıToR: Güven Kayaoğlu, Gazi University, Ankara, Turkey

Copyright: ( 2018 Gülşen et al. This work is licensed under a Creative Commons Attribution License. Unrestricted use, distribution and reproduction in any medium is permitted provided the original author and source are credited.

FundING: None declared.

CONFLICT OF INTEREST: The authors declare no conflict of interest related to this study.

\section{INTRODUCTION}

Patients with a cleft lip and palate (CLP) are a specific patient group requiring long-term multidisciplinary approaches from infancy to adulthood. Given the longterm treatment requirement, the prediction is needed for the resulting improvement in the dentofacial structures of patients. Similar to the surgical approaches, the orthodontic treatment plan needs to be anticipated at an early stage. A well-controlled treatment plan is executable if the clinician has a command on the expected alterations in the dentofacial structure.

Subsequent to the presence of the cleft, reduction in the maxillary interdental width and tooth width is generally observed. ${ }^{1,2}$ In addition, mandibular arch dimensions may be affected in conjunction with the changes in the maxillary arch. ${ }^{3}$

Considering the requirement of exact evaluation of tooth size for achieving an esthetic, stable, and functional occlusal relationship, awareness about the variations in tooth size in patients with CLP may guide clinicians in orthodontic and accompanying dental treatment planning. Therefore, many studies evaluated tooth size in patients with CLP.1,4-6 These studies revealed varied findings in terms of tooth size. In general, teeth in patients with CLP were reported to be smaller. In contrast, some studies ${ }^{5,6}$ indicated that certain teeth were larger in patients with CLP than in controls, while others found no difference. ${ }^{7}$ However, considering mesiodistal tooth dimensions in patients with a nonsyndromic unilateral CLP (UCLP), the previous meta-analysis reported that tooth size of these patients tended to be larger than those of the general population. ${ }^{1}$ Additionally, the difference in tooth size 
between the sides with and without the cleft has also been described in patients with UCLP. , $^{1,5,8}$

Maxillary dental and skeletal dimensions in patients with CLP have been studied extensively. Previous studies reported a statistically significant narrow maxillary arch. ${ }^{3,9}$ However, information on mandibular arch widths in patients with CLP is limited. Athanasiou et $a l .{ }^{10}$ studied the transverse dentofacial morphology of 64 children with an isolated cleft palate at the ages of 3-4, 8-9, and 12 years and reported no difference in the bigonial width of the mandible between patients with an isolated cleft palate and controls. Celikoglu et al. ${ }^{11}$ used CBCT images and reported that UCLP, bilateral CLP (BCLP), and control groups had similar bigonial width values, indicating that the type and presence of cleft did not affect the mandibular skeletal transverse width. They ${ }^{11}$ mentioned that patients with BCLP and UCLP had statistically significant lower intercanine alveolar widths and larger intermolar and intermolar alveolar widths compared with the normal occlusion group. Heidbuchel and Kuijpers-Jagtman ${ }^{3}$ demonstrated a slight decrease in the anterior and posterior regions of the mandibular arch as an adaptation to the maxillary arch in patients with CLP. Fudalej et al. ${ }^{12}$ reported that the mandible was retrusive and the length of the mandibular body was $2 \mathrm{~mm}$ shorter in patients with CLP than in controls. Similarly, Swennen et al. ${ }^{13}$ reported that UCLP and BCLP groups had a shorter mandibular body compared with controls.

A reduction in intercanine width with an increase in intermolar width, reduction in tooth size with a greater premolar width, and shorter mandibular length may have conflicting effects on mandibular dental alignment in patients with CLP. No study to date investigated the discrepancy in the mandibular arch length in patients with CLP. This study aimed to assess the discrepancy in the lower arch length in a group of patients with a nonsyndromic UCLP.

\section{Materials and Method}

This study involved pretreatment orthodontic models and panoramic radiographs of patients with complete UCLP who were treated at the Department of Orthodontics and Department of Plastic Reconstruction and Esthetic Surgery in Gazi University.

As a routine procedure at the beginning of the orthodontic therapy, patients and/or patients' parents signed an informed consent form, allowing the researchers to use their data for scientific purposes. The study was approved by the ethical committee of the Gazi University (2018-42).

Patients with large restorations/crowns, tooth agenesis, impacted or supernumerary teeth in the lower arch, previous orthodontic and/or prosthetic treatment, systemic diseases, developmental or acquired craniofacial muscular deformities, syndromes, endocrine abnormalities, and neurological problems were excluded from the study.

The study sample consisted of 23 Caucasian patients (12 female and 11 male; age 9-19 years) with complete UCLP. Six of the patients had late mixed dentition with permanent lower canines erupted and 17 had permanent dentition.

The same examiner assessed the lower arch discrepancies on dental models. A digital caliper accurate to $0.01 \mathrm{~mm}$ (Mitutoyo, Kanazawa, Japan) was used for assessing tooth width and arch length. Tooth width was measured as the longest distance between the anatomic mesial contact point to the distal contact point. The arch length was measured from the mesial contact point of the first molar, through the mesial and distal contact points of the posterior teeth and incisal edges of the anterior teeth, to the mesial contact point of the opposite first molar (Figure 1). Panoramic radiographs of high quality were used to estimate the size of permanent premolars for the patients with mixed dentition. The magnification rate was corrected to obtain real tooth width.

Hayes-Nance analysis ${ }^{14}$ was used to determine lower arch discrepancies. The positive discrepancy in the lower arch length defined the diastema, whereas the negative discrepancy defined crowding in the lower arch.

The examiner repeated all the measurements after an interval of 20 days to assess the magnitude of methodological error. The observer was also blinded to the previously completed measurements. The methodological error and intraobserver reliability were determined using Dahlberg's formula; $\mathrm{Si}=\sqrt{\sum} \mathrm{d}^{2} / 2 \mathrm{n}$ ( $d$ is the difference between two measurements of a pair, and $\mathrm{n}$ is the number of double measurements) and paired t tests.

\section{Statistical analysis}

Data were analyzed using the Statistical Package for Social Sciences (SPSS) version 22 software (SPSS Inc, Chicago, IL, USA). They were expressed as the mean \pm standard deviation. Descriptive statistics were presented using frequencies and percentages, and the differences were evaluated using the binomial test.

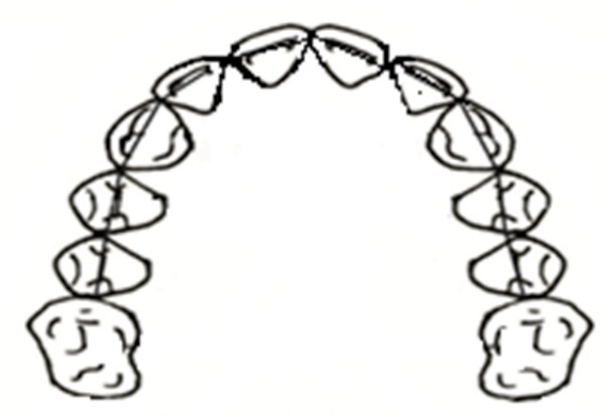

Figure 1. Arch length measurements on dental models 
Table 1. Descriptive analysis of the discrepancy $(\mathrm{mm})$ in the arch length in patients with a UCLP $(n=22$; the patient who did not have any discrepancy was excluded)

\begin{tabular}{lllllll}
\hline & $\mathrm{n}$ & Mean & $\mathrm{SD}$ & Median & Minimum & Maximum \\
\hline Positive (+) & 10 & 3.6 & 1.9 & 3.5 & 1.6 & 7.0 \\
Negative (-) & 12 & -2.9 & 1.4 & -3.0 & -0.3 & -5.0 \\
\hline
\end{tabular}

(+): diastema; (-): crowding; SD: standard deviation

\section{REsULtS}

The methodological error did not exceed $0.25 \mathrm{~mm}$, while the repeated measurements were not significantly different $(p>0.05)$.

Considering the discrepancy in the arch length, only 1 out of 23 patients had no discrepancy in the lower arch. In the remaining patients $(n=22)$ the prevalence of diastema was $47.8 \%(n=10)$ with a mean value of $3.6 \pm 1.9 \mathrm{~mm}$. Lower arch crowding was observed in $52.16 \%(n=12)$ with a mean value of $-2.9 \pm 1.4 \mathrm{~mm}$ (Table 1). No significant difference was found between the prevalence of crowding and diastema $(p=0.832)$.

\section{Discussion}

No study to date assessed the discrepancy in the mandibular arch perimeters in patients with UCLP. This study assessed the mandibular dental arch deficiency using dental cast measurements. It found that the discrepancy in the arch length ranged from diastema to moderate crowding regardless of gender differences in patients with nonsyndromic UCLP. No significant differences in frequencies of diastema and crowding were found in the lower arch. No severe crowding was detected. The results of the present study could not be compared with previous studies because no similar study was performed in the past.

The discrepancy in the maxillary arch was not evaluated because standardization might not be achieved due to differentiated primary surgical techniques, early orthopedic treatment applications, number and size anomalies of the teeth, and shape and size of the cleft in each patient.

Previous findings on the effect of sex on tooth width are contradictory. ${ }^{15-19}$ However, significant differences in tooth size between the sexes have been reported. ${ }^{15,16}$ Males with a UCLP were reported to have larger teeth than females. ${ }^{15}$ In addition, males seemed to have larger mandibular width and length compared with females. ${ }^{20}$ Larger tooth with larger dimensions of mandibula may eliminate the resulting effect on the discrepancy in the arch length. Therefore, the number of male and female patients was matched and they were put in the same pool in the present study. Similar to the study by Akçam et $a l .{ }^{6}$ the patients were not divided into groups according to sex in this study so as not to reduce the number of patients by dividing them into subgroups.
Caucasian patients with the same ethnicity were included in the study to eliminate the ethnic and racial differences because tooth sizes are population specific and the discrepancy in tooth size varies between different ethnic groups and races. ${ }^{16,21-24}$

Previous studies reported differences in tooth size between patients with a CLP and normal occlusion. ${ }^{6,25,26}$ In general, reduction in tooth size in patients with a CLP was emphasized. $4,8,27$ Diastema can be expected in mandibular arch considering the reduction in tooth width. Additionally, lower tongue position in these patients due to the narrow scarred maxilla, which increased the mandibular intermolar width, and class III tendency, with negative overjet eliminating the restriction of maxillary teeth, may be predisposing factors in the occurrence of diastema. However, this was not confirmed by the present study. In this study, diastema was observed in $47.8 \%$ of the sample, ranging between 1.6 and $7 \mathrm{~mm}$. It could be attributed to the lingoversion tendency of the mandibular teeth as means of adaptation to the narrow maxillary arch and achievement of a proper chewing function, which eventually results in the dental arch collapse.

Wahaj and Ahmed ${ }^{28}$ compared the arch dimensions (both intercanine and intermolar width) between the CLP and normal class I occlusion groups. They found that the maxillary and mandibular intercanine widths significantly reduced in the CLP group (both unilateral and bilateral) compared with the normal class I occlusion group. The decrease in the mandibular intercanine width might be due to the lower maxillary intercanine width, leading to the adaptation of the mandibular intercanine width. The reduction in intercanine width might cause a reduction in arch length. A greater premolar teeth width might increase the acquired arch length, leading to crowding tendency. ${ }^{6,28}$ In this study, the crowding in the lower arch was found to be minimum $(1-3 \mathrm{~mm})$ to moderate $(3.1-6 \mathrm{~mm})$. No severe crowding (>6 mm) occurred; the maximum crowding was $5 \mathrm{~mm}$ and minimum $0.3 \mathrm{~mm}$. No patient had crowding of $7 \mathrm{~mm}$ or more, indicating extraction.

Studies often tend to have small sample sizes, leading to bias in the interpretation of results. ${ }^{4}$ The limitation of this study was also the small sample size due to its retrospective design. Achieving sufficient number of patients with the same characteristics in this special patient group is difficult. Additionally, this study did not include a control group. Participants with normal facial morphology and class I occlusion or participants with class III occlusion could not be used as a control group because the patient might have a wide range of crowding (mild to severe) in each occlusion type. Therefore, no control group was selected to avoid bias.

Further studies with large sample size are needed to validate the findings of this study. Additionally, studies comparing the discrepancy in the arch length in patients with a UCLP and BCLP are necessary. 


\section{Conclusion}

Despite the limitations, the present study indicated that the frequency of encountering diastema and crowding in the lower arch was approximately the same in patients with UCLP. The crowding was of a minimum to a moderate level. It did not exceed $5 \mathrm{~mm}$, which is an important point to be considered for precise orthodontic treatment planning in patients with a CLP.

\section{ACKNOWLEDGEMENT}

This study was presented as a poster presentation at the XVth International Congress of the Turkish Orthodontic Society, October 1-5, 2016, Antalya, Turkey.

\section{REFERENCES}

1. Antonarakis GS, Tsiouli $K$, Christou $P$. Mesiodistal tooth size in nonsyndromic unilateral cleft lip and palate patients: a meta-analysis. Clin Oral Invest 2013;17:365-77.

2. Walker SC, Rye Mattick C, Hobson RS, Steen IN. Abnormal tooth size and morphology in subjects with cleft lip and/or palate in the north of England. Eur J Orthod 2009;31:68-75.

3. Heidbuchel KL, Kuijpers-Jagtman AM. Maxillary and mandibular dental-arch dimensions and occlusion in bilateral cleft lip and palate patients form 3 to 17 years of age. Cleft Palate Craniofac J 1997;34:21-6.

4. Lewis BR, Stern MR, Willmot DR. Maxillary anterior tooth size and arch dimensions in unilateral cleft lip and palate. Cleft Palate Craniofac J 2008;45:639-46.

5. Rawashdeh MA, Bakir IF. The crown size and sexual dimorphism of permanent teeth in Jordanian cleft lip and palate patients. Cleft Palate Craniofac J 2007;44:155-62.

6. Akcam MO, Toygar TU, Özer L, Özdemir B. Evaluation of 3-dimensional tooth crown size in cleft lip and palate patients. Am J Orthod Dentofacial Orthop 2008;134:85-92.

7. Peterka M, Müllerová Z. Tooth size in children with cleft lip and palate. Cleft Palate J 1983;20:307-13.

8. Werner SP, Harris EF. Odontometrics of the permanent teeth in cleft lip and palate: systemic size reduction and amplified asymmetry. Cleft Palate J 1989;26:36-41.

9. Ye B, Ruan C, Hu J, Yang Y, Ghosh A, Jana S. et al. A comparative study on dental arch morphology in adult unoperated and operated cleft palate patients. J Craniofac Surg 2010;21:811-5.

10. Athanasiou AE, Moyers RE, Mazaheri M, Toutoutzakis N. Frontal cephalometric evaluation of transverse dentofacial morphology and growth of children with isolated cleft-palate. J Craniomaxillofac Surg 1991;19:249-53.

11. Celikoglu M, Buyuk SK, Ekizer A, Sekerci AE. Evaluation of mandibular transverse widths in patients affected by unilateral and bilateral cleft lip and palate using cone beam computed tomography. Angle Orthod 2015;85:611-5.

12. Fudalej P, Obloj B, Dudkiewicz Z, Hortis-Dzierzbicka M. Mandibular Morphology and Spatial Position Following One-Stage Simultaneous Repair of Complete Unilateral Cleft Lip and Palate. Cleft Palate Craniofac J 2008;45:272-7.

13. Swennen G, Berten JL, Kramer FJ, Malevez C, De Mey A, Schwestka-Polly R, et al. Mandibular morphology in complete unilateral cleft lip and palate. Cleft Palate Craniofac J 2004;41:403-9.

14. Erdemir U, Yucel T, Yildiz E, Germec Cakan D, Sayinsu K. Dental Analysis. Erdemir U, Yildiz E, editors. Esthetic and Functional Management of Diastema. Zurich: Springer; 2016. p.101-20.

15. Bunyarit SS, Asma AA, Abdul Rahman NA, Adri SS, Rahman MM. Dental Anomalies and Gender Dimorphism in Tooth Size of Malay
Patients. Bangladesh Journal of Medical Science 2017;16:115-21.

16. Kumar TVP, Chitra P. Determination of Bolton Norms for Indian Population Sample. Orthodontic Journal of Nepal 2018;7:33-6.

17. Wolfart S, Menzel H, Kern M. Inability to relate tooth forms to face shape and gender. Eur J Oral Sci 2004;112:471-6.

18. Smith SS, Buschang $\mathrm{PH}$, Watanabe $\mathrm{E}$. Interarch tooth size relationships of 3 populations: "does Bolton's analysis apply?" Am J Orthod Dentofacial Orthop 2000;117:169-74.

19. Santoro M, Ayoub ME, Pardi VA, Cangialosi TJ. Mesiodistal crown dimensions and tooth size discrepancy of the permanent dentition of Dominican Americans. Angle Orthod 2000;70:303-7.

20. Sugiki $Y$, Kobayashi $Y$, Uozu M, Endo T. Association between skeletal morphology and agenesis of all four third molars in Japanese orthodontic patients. Odontology 2018;106:282-6.

21. Bailit HL. Dental variation among populations. An anthropologic view. Dent Clin North Am 1975;19:125-39.

22. Bishara SE, Garcia AF, Jakobsen JR, Fahl JA. Mesiodistal crown dimensions in Mexico and the United States. Angle Orthod 1986;56:315-23.

23. Omar H, Alhajrasi $M$, Felemban $N$, Hassan A. Dental arch dimensions, form and tooth size ratio among a Saudi sample. Saudi Med J 2018;39:86-91.

24. Fernandes TM, Sathler R, Natalício GL, Henriques JFC, Pinzan A. Comparison of mesiodistal tooth widths in Caucasian, African and Japanese individuals with Brazilian ancestry and normal occlusion. Dental Press J Orthod 2013;18:130-5.

25. Garn SM, Osborne RH, McCabe KD. The effect of prenatal factors on crown dimensions. Am J Phys Anthropol 1979;51:665-78.

26. Foster TD, Lavelle CL. The size of the dentition in complete cleft lip and palate. Cleft Palate J 1971;8:177-84.

27. Lai MC, King NM, Wong HM. Abnormalities of maxillary anterior teeth in Chinese children with cleft lip and palate. Cleft Palate Craniofac J 2009;46:58-64.

28. Wahaj A, Ahmed I. Comparison of Intercanine and Intermolar Width Between Cleft Lip Palate and Normal Class I Occlusion Group. J Coll Physicians Surg Pak 2015;25:811-4.

\section{Tek taraflı dudak ve damak yarığına sahip hastalarda alt çene ark boyu uyumsuzluğu: ortodontik model analizi}

\section{ÖZET}

AMAÇ: Tek taraflı dudak ve damak yarığına (DDY) sahip hastalarda alt çene ark boyu uyumsuzluğunu belirlemektir.

Gereç Ve Yöntem: Non-sendromik tek taraflı total DDY'ye sahip olup, alt çenede büyük dolgu/kronlu diş bulunmayan, diş eksikliği, gömülü veya fazla dişi olmayan kronolojik yaşı 9 ile 19 yıl arasında değişen 23 hastaya ait tedavi öncesi panoramik radyograf ve ortodontik modeller değerlendirildi. Hastaların dudak ve damak yarığı opere edilmiştir. Alt ark boyu uyumsuzluğunu belirlemede Hayes-Nance analizi kullanıldı. Geç karışık dişlenme dönemindeki hastalar için daimi premolar boyutları panoramik radyograflarla değerlendirildi. Pozitif ark boyu uyumsuzluğu diastema, negatif ark boyu uyumsuzluğu çapraşıklık olarak kabul edildi. Tanımlayıcı istatistikler sıklık ve yüzde oranları kullanılarak yapıldı ve farklar binomial test ile değerlendirildi. 
BULGULAR: İncelenen 23 hasta içinde sadece bir hastada ark boyu uyumsuzluğu görülmedi. Kalan 22 hastanın \% 47.8'inde $(n=10)$ diastema saptandı; bu miktar ortalama $3.6 \pm 1.9 \mathrm{~mm}$ olarak bulundu. Alt ark çapraşıklığı ise \%52.2 $(n=12)$, prevalans ile ortalama $-2.9 \pm 1.4 \mathrm{~mm}$ olarak bulundu. Çapraşıklık ve diastema prevalansları bakımından istatistiksel olarak önemli bir fark bulunmadı $(p=0.832)$.

Sonuç: Tek taraflı DDY'ye sahip hastalarda, alt çenede, diastema ve çapraşıklığa aynı prevalansta rastlanabilmektedir. Görülen çapraşıklık hafif ile orta şiddettedir.

Anahtar Kelimeler: Arkus dentalis; çapraşıklık; diyastem 